\title{
Analysis of the Cultural Connotation of Taoist Ritual Literature in the Northern Dynasty
}

\author{
Mengmeng Zhou \\ College of Liberal Arts \\ Northwest University for Nationalities \\ Lanzhou, Gansu, China 730030
}

\begin{abstract}
The study of Taoist ritual literature is about the literature content related to the ritual, literature restrict the development of ritual literature, the ritual also determines the characteristics of ritual literature, and the two are interdependent and mutually restrictive. Taoist ritual literature in the Northern Dynasties as an important factor of the development of literature and Taoism in the Northern Dynasties, has the dual value in both religion and literature, thus deserves further study. This paper focuses on the classification and exploration of the cultural connotations of the Taoist ritual literature in the Northern Dynasties, indicate it use a unique expression to described the grand welcome scene when the gods "came down to the earth" through the dialogue with the gods, expressed the expectations and wishes for a prosperous country and peaceful people, so as to achieve the purpose of dispel misfortune for human.
\end{abstract}

Keywords-Northern Dynasty; Taoist ritual; cultural connotation

\section{INTRODUCTION}

Taoist ritual literature in the Northern Dynasties was literary works produced by the Taoists who professional engaged in Taoist activities and the literati who create Taoist ritual themes during the Taoist rituals.

In Taoist rituals, the practitioners communicate with the gods through unique mysticism and the art of enlightenment, and enter the state of absolute freedom of body and soul. They created a lot of fabulous fantastic, illusory wonderland, summed up, these delightful mood can be divided into three realms, namely, the heavenly wonderland, wonderland on the earth, wonderland in hell three realms. Heavenly Wonderland is the place a lot of Taoist fascist and strongly depicted, where the scene is different, some with gorgeous colors, mysterious and magnificent, some are fresh and natural, green rivers and foggy mountains. Here both has brutal battles and a prosperous scene of harmony, these are the illusory reflections of the real world in heaven. In addition to the Heavenly Wonderland, there are fairy mountains immortals lived in and immortals, these imaginary products together create a fascinating wonderland which help people to get rid of evil, dissipation of the disaster, sent good karmic, but also absorbed by some literati during the creation of Taoism Songs and $\mathrm{Bu} \mathrm{Xu} \mathrm{Ci}$. Besides this type, there are hell which looks very terrible in ordinary people's eyes, but there are also beautiful landscape in hell in Taoist's eyes, here also have things and landscapes which bring happiness to numerous people, many of the dead people and even the supreme emperors will enjoy their very happy happiness here too.

Although the length of the Northern Dynasties Taoist ritual literature is not long, but also it use a unique expression to described the grand welcome scene when the gods "came down to the earth" through the dialogue with the gods, expressed the expectations and wishes for a prosperous country and peaceful people, so as to achieve the purpose of dispel misfortune for human.

\section{The Ultimate PURPOSE TO DisPEL MisfortunE THROUGH THE BLESSING OF GOD}

The songs and poems in the Taoist rituals of the Northern Dynasties have a strong religious nature, it emerged a large number of immortal figures and their ultimate purpose is to dispel misfortune through the blessing of God.

The ritual mentioned in "Yuanshi Tianzun Shuobianhua Kongdong Miaojing" in accordance with the different solar terms recorded Taoist rituals from the beginning of Spring to The winter solstice a total of eight periods. The ritual held on the day of the beginning of the spring, this day is Gao Zhen God gathered Tai Chi immortals in the Tai Chi palace, before the mantra he committed his "Shenni eguo,nanshe zhicheng, buyuan zhizui" [1](Past bad behaviors, mistakes difficult to forgive, sins not original).Spell the mantra means to beg Gao Zhen god and Tai Chi immortals to "Qichu suguo, xiaomie zuigen"(forgive the mistakes, eliminate the root of sin),"Yangxiang xuanen, wanyuan kehui, mibu ruyan"(Enjoy the blessing and all the wishes will be satisfied); At the spring equinox day, "Jianxiao boji, luozui lesheng, wudi dinglu, donghua jiming, daohe shangyuan, wobing miaojing."[1] This day, the Kunlun Yao Tai Tai Su Zhenren gathered all the immortal officials on the Yaodai to check the achievements of scholars. Therefore, before the mantra they will introspect the forbidden things they commit since they start learning, "Weifu jingke, Louman tiaanwen qingxie zhizui" (violation of disciplines, sins to leak the heaven's mystery), while begging to eliminate the committed sins, delay the punishment, stay away from human suffering, make the soul rise to immortality. The content of this spell is similar to that of other time slots. It can be seen that although the pledge object is different gods, 
the content of the prayer is different, but the purpose is to dispel misfortune through the blessing of God.

The Taoist ritual in "Zhengyi Chitanyi", social psychology about dispel misfortune is disclosed through the good and evil judgment of ghosts this twists and turns form. Such as: "Jinqing Dongfang Qingtong jun,...Jianglin tansuo, Xingshen buqi Sousuo xiejing, Quchu guizei, Youzui wushe."(I would like to welcome the East Qing Tong Jun, ..., descending the altar, conduct its magic power, search evil spirit, get rid of ghost thieves, consider guilty). [2] Here, the ghosts and gods are clearly divided into two camps. The heavenly generals and soldiers which headed by East Qing Tong Jun, Southern Chi Tong Jun and other five gods under the author's pen appeared as the good God to exorcise the evil, and was praised by regarding it stand on the same side. The ghost is a symbol of disaster and evil, and only search for evil spirits, expel and burn the ghost could avoid punishment. For the evil forces continue to put up a stiff resistance, the author has no polite, all considered "guilty", put it categorically with very firm attitude. The various spells and blessings of Taoist rituals all consider the production of disaster are the role of the devil, to dispel the disaster is to suppress the evil, so the basic tone is nervous and intense, the work from time to time outbreak collision sound of swords and spears, seems a large-scale war is going on. However, there are also some relaxed description, such as "Xiangyan yunv, zhenling linjiang, chuici buze, shangsheng tiangong, xiangyan feisan, yudao hehe" [3] (Incense smoke and beautiful ladies, real gods arrived, blessing all the world and people, rise up to the heaven palace, the incense smoke disappear, harmony with the heaven and earth), which presents a peaceful scene of all things blessed and combined with Tao into one. "Zhutian yongqingyin, miaomiao feiyunduan. Qunsheng geyunqu, yunv changxuanhuan. Tongyou wangmushi, paihuai qiongtangguan. Zhongxian yuhuazhi, canyao yingyulan."[5] (The heavens are full of beautiful and clear voices, and spread into the far clouds. Group immortals sing the cloud song, goddess sing the Xuan huan song. Travel together in the Queen Mother palace, wandering in Qiongtang to watch. All the immortals have jade and crystal quality, shining broadly). Totally as scene of elegant songs and refined dancing, as if just won a great victory and now is holding a celebration ceremony, it tells the believers that after the battle of gods, evil will eventually be destroyed, which psychologically eliminate the fear of the disaster. Author's such arrangement apparently has a soothing intent.

All in all, $\mathrm{Bu} \mathrm{Xu}$, mantra blessing and such content in the Taoist ritual of the Northern Dynasties all tell the believers that: The ending is good, after the battle of gods, evil will eventually be destroyed, which psychologically eliminate the fear of the disaster. From this point of view, it has a reassurance role in a particular historical condition. To be specific, in order to achieve the ultimate purpose of praying for the people to dispel the misfortune, the Northern Dynasties Taoist ritual literature seems only with single form but it contains a rich content.

\section{DESCRIBE THE GRAND SCENE OF THE GODS "ARRIVED AND BE WELCOMED”}

In the Taoist sacrificial rites, the description about the grand scene of the gods "arrived and be welcomed" accounts for a large proportion in its Mantra, blessing and other content. The grand scene not only because the welcomed god has a very important position an the figure is magnificence, but also because the gorgeous dress, the numerous attendants, all things together harmony, divine and the whole world are in good communication ... such as "Orthodox Taoist Canon" 1st Volume "Shangqingdong Zentianbao Dadong Sanjing Baolu" has a lot of similar scenes. When the Suixing Zhenjun "arrived and be welcomed", the sky light combined with all things, the essence of heaven and earth slowly flow, flying rosy clouds shining scattered all through the nine directions, and his wife Fei Yun " Qifu lingjin, longpei huqun, yaodai fengfu, shoujin huaguan, chuwu ruxu, aoyou taiyuan."[4] Her clothing is extremely gorgeous," before led by Qingdi, after followed by thousands of God", making people can not help to think of the solemn and grand scene of welcoming God, people shocked. At the time to meet Chidi, it is stated that "Xuanxiangliuying, Danguangnanming, Yangwangsanmen, Zhuyunjiangchen, Zhongyoudanhuang, Mingyueweiting, Furenneizhao, Shiweihuaping, Qifuyunshuang, Fenghualongling, Yaodaihushu, Shoujinfeiqing, Chuyuanruxuan, Xiangaowucheng, Qiandaochidi, Houcongliuding, Laijianzhaoting, Dezhenzhiming, Shangdengxuanxu, Jinshuyuqing."[4] Except the gods to meet is different, all the phenomena in the world, entourage, clothing, and so have shown the same grand scene for greeting age-year-old Zhenjun.

\section{THE EXPRESSION OF THE VISION OF THE IMMORTAL WORLD AND LONGING}

In the rituals of Taoism, practitioners of Taoist rituals, in the rituals of Taoist rituals, or in the rituals of Taoism, or in many rituals, in many rituals, Through a variety of ways out of the gods, or to express the praise of the gods or depicting the immortal world of China and the United States, no matter which way through the immortal world embodies the endless longing and yearning.

In "Orthodox Taoist Canon . Department Dongxuan · Class Benwen · Shangqingdong Xuanmingdeng Shangjing", it said "Taishang sanshifang, huadeng tongjingcheng, zhutian jieheran, zhudi xilangming, woshen yiguangche."[5] This is the immortal world which shined through by lights in the light ritual, lanterns illuminate the heaven and earth, all things are impressively, extremely clear, also illuminated me, shine into my internal organs, so that my soul is detached. "Yeguang biaoyangdan, tiaotiao zhaolingshi, zhutian puguangxian, zhuyin jiyimie, woshen yicongming, changwan zhiyuhui, xiaoyao shidaoyun, qianxie rentianshi, juxing niekongdong, yezhu huanliucui."[5] Here is a further description of the things under the light of lanterns, while making those who symbolize disaster and evil things gradually perish, but also praised the wisdom of the gods, so that all things live happily and harmony. These all contain eulogists' praise of the gods and their longing to a world full of brightness and peace. 
As a drop in troubled world, many scholars also showed unlimited fantasy and expectations for the immortal world. Such as literati $\mathrm{Yu}$ Xin who is inexcusable to be longing for the immortal theory. As his ten poems said: "Chengdan xuzhujie, kesui yongludao. Wufang yinshiqu, jishi xianrentao." [6] It expressed the poet's eager for the cloistered life and his feelings and interests to travel with immortals and forget human troubles.

\section{EXPRESS THE EXPECTATIONS AND WISHES OF A \\ CONTENTEd People Living in a COUNTRy at PEACE}

Taoism has a great development in the Northern Dynasties and it is inseparable with the chaos social environment and the impetus of Governor, famous clans and literati. All these determined that the existence and development of Taoism in the Northern Dynasties should depend on the social reality at that time, with strong secularity. As an important factor of the Taoist literature in the Northern Dynasties, the praise, mantra and blessing and other literary contents in the Taoist rituals of the Northern Dynasties not only have a strong religious character, but also the reality is one of its important characteristics. Whether through sarcasm, criticism, or helpless sigh, the literature produced by the Taoist rituals of the Northern Dynasties also permeated with the author's expectation and wishes for a contented people living in a country at peace, and the longing and wishes for a better and prosperity country.

The existing ten poems of $\mathrm{Yu}$ Xin "Taoist $\mathrm{Bu} \mathrm{Xu} \mathrm{Ci",} \mathrm{is}$ the representative of the literati $\mathrm{Bu} \mathrm{Xu} \mathrm{Ci}$ of the Northern Dynasties period, and also the concentrated expression of its immortal thoughts. Such as the ninth poem: "Fengfang dezhujin,. Hanwu duojiaoman, huainan buxiaoxin. Penglai ruhaidi, hechu kezuixun." [6] It contains the poet's criticism for Emperor Hanwu and King of Huainan Liu'an's excessive and blind immortal worship. From Yu Xin's view, Penglai Wonderland is not real but rather illusory with no trace can be found, but the governors are benighted, unable to see the fact through mysterious, even consuming a lot of manpower, material and financial resources to pursue a beautiful bubble, in any case they can not achieve the immortal wonderland.

Yu Xin 's "Bu Xu Ci" though accepting the Taoist theory on the evolution of heaven and earth as well as the idea of Yanggushen, Shoushanshui and Fuzhicao, but it is ironic to the behavior of the governor seeking the immortals. The ninth poem not only reflected his criticism of the foolish governor,but also expressed his deep disappointment in the searching activity for the Penglai wonderland. Another example is the eighth poem, Shangyuan fengyusan, zhongtian gechuifen. Lingjia qianxunshang, kongxiang wanliwen" [7] It seems to express the poet's desire to seek immortality, but in fact contains a deep irony. "Wind and rain" "scattered", "song and play" stopped, it is an alluding to the ruling class excessively indulge in immortality, lead to the emptiness of national center, which will inevitably lead the country from unity toward division. These all have very strong reality, express the poet's deep concern for the fate of the country and the expectations for a stable and prosperous country.

\section{CONCLUSION}

The study of Taoist ritual literature is related to the content of ritual literature and the development of ritual literature. The ritual also determines the characteristics of ritual literature, which are interdependent and mutually restrictive. Through the exploration of the Taoist ritual literature in the Northern Dynasties, it can be found that although the quantity is less than that of the Southern Dynasties, the ideological implication may not be as deep as that of the Tang and Song dynasties, but we can glimpse the strange sparks when they meet together. In this world, they consider the misfortune dispel are the purpose of the world, integrate with the gods into one, depict fantasy immortal world and the grand scene of gods "arrived and be welcomed" selflessly, express their longings for the immortal world, contains their expectations and wishes of a contented people living in a country at peace.

\section{REFERENCES}

[1] Orthodox Taoist Canon. Yuanshi Tianzun shuo bianhua kongdong miaojing. 1st Volume [M]. Taipei: Arts Press, 1977: 846-859.

[2] Orthodox Taoist Canon.Zhengyi Shitanyi, Department Dongshen, Weiyi class. 18th Volume [M]. Taipei: Arts Press, 1977: 295-296.

[3] Orthodox Taoist Canon - Department Dongshen, Fangfa class,Jiaoyi. 18th Volume [M]. Taipei: Arts Press, 1977: 562.

[4] Orthodox Taoist Canon.Shangqingdong Zhentianbao dadong sanjingbaolu, 34th Volume [M]. Taipei: Arts Press, 1977: 101-126.

[5] Orthodox Taoist Canon. Department of DongXuan, Benbu class. 6th Volume [M]. Taipei: Arts Press, 1977: 251-252.

[6] (Northern Zhou) Yu Xin wrote, (Qing) Ni Fan Note. Yuzishan jizhu [M]. Beijing: Zhonghua Book Company, 1980: P400.

[7] (Northern Zhou) Yu Xin wrote, (Qing) Ni Fan Note. Yuzishan jizhu [M]. Beijing: Zhonghua Book Company, 1980: P399.

[8] Zhu Yueli. Taoist Canon classification and problem solving [M]. Beijing: Huaxia Publishing Company, 1996.

[9] Chen Guofu,Origin of the Taoist Canon [M]. Beijing: Zhonghua Book Company, 1949. 